\title{
浅谈班主任如何建立良好的师生关系
}

廖兰兰

广西省南宁市明天学校

DOI:10.32629/jief.v2i5.1409

[摘 要] 在一个班集体中, 班主任是引导学生更好地学习和成长的关键性角色, 因此作为一个班的班主任, 不仅要关注学习者的单科成绩和 能力, 还要协调学习者各方面的成长, 促进学生的全面发展。在这一过程中, 让班主任跟学生建立好良好的师生关系, 是发挥班主任重要作 用，促进学生全面协调发展的关键。这篇文章对班主任老师如何和学生建立好关系进行了简要的分析。

[关键词] 班主任; 师生关系; 建立巩固

中图分类号: G635.1 文献标识码: A

好的师生关系是班主任老师做好教务工作的基础。学生是学习的主 体, 而班主任老师是他们人生路上的一个引领者, 他能够影响学生的一 生。然而, 作为班主任不仅要有较高的教学素养, 还要能够更好地与学 生和家长沟通。因此, 做好教务工作并建立好师生关系, 也是班主任的 重要工作之一。

\section{1 班主任老师在与学生建立关系时容易出现的问题}

班主任在建立师生关系的时候, 受各种因素的影响, 会出现一些大 大小小的问题, 这些问题涉及到他们和学生、家长之间的沟通, 也常常 影响着学生的成长和发展, 影响着学生三观和人格的塑造, 而如何解决 这些问题也就成为了众多班主任老师应该思考的问题。

1.1 师生之间关系不对等。师生之间关系的不对等是阻碍学生和老 师建立良好师生关系的根本因素。在教育教学中, 学生是受教育的主体, 有着极强的可塑性, 但师生关系的不对等使学生处在弱势地位, 主体地 位受到影响。与此同时, 这种不对等奠定了班主任老师的权威性地位, 学生有什么事不敢告诉老师, 惧怕老师, 师生关系自然建立不好, 这就 是师生之间关系不对等的情况。一般出现这样的情况, 老师要注意反思 自己身上的问题, 找出问题的根源。

1.2 过于苛责学生, 忽视学生之间的差异, 导致学生惧怕老师, 老 师也因此无法服众。大部分班主任老师在面对不同学生的时候还是可以 公平对待的, 但有一部分老师对优秀的学生十分赞许, 对待差生十分严 厉, 甚至讽刺差生、批评差生, 这就容易导致学生对老师产生厌恶感, 学生不喜欢老师, 师生关系自然就越来越差。

1.3 自身修养和专业素养难以服众。作为老师, 应当具有较高的专 业能力和水平, 老师的专业素养难以服众, 水平又不够高, 就会导致学 生不信任老师的能力, 对老师的能力产生怀疑。老师在学生眼里能力欠 缺、知识不足, 自然难以让学生信服他, 更没法和学生建立好师生关系。

这就是班主任在与学生建立师生关系时遇到的各种问题。这些问题 严重影响了学生对老师的印象, 影响了学生的学习兴趣以及三观, 不利 于学生的成长。为了解决这些问题, 老师应该做好充分的准备, 在不断 提升自己的过程中找出问题根源, 解决问题。

\section{2 班主任老师建立师生关系的基本策略}

2.1 建设自身形象, 提高专业素质与个人修养, 做好为人师表的典 范。老师是学生的榜样、典范以及领路人, 班主任老师更是一个管理整
个班级, 做好班级工作的关键人物。班主任老师想处理好与学生的关系, 最重要的就是建立良好的个人形象, 从根本上提高个人的专业能力和修 养, 做好为人师表的典范, 做好各位老师争当的楷模和榜样, 这是建立 好师生关系的主要途径。

2.2 坚持正确的师生观。作为班主任老师, 应该尊重差异, 多鼓励 和赞许学生。不同的人擅长的东西不同, 性格各异, 作为班主任应该平 等对待每一个学生, 对学生要多引导和鼓励, 同时还形成正确的师生观, 保障学生受到公平的对待, 帮助学生全面发展, 这样学生才会喜欢老师, 师生关系才能越来越好。

2.3 主动与学生沟通, 关心学生。班主任老师作为班集体的引领人, 对班上的每个学生都负有一定的责任。因此, 主动与学生沟通、关心学 生、爱护学生, 及时了解每位同学的情况, 是班主任的责任, 也是班主 任老师建立好师生关系的群众基础。只有让学生感受到老师对自己的关 心关怀, 学生才能更喜欢老师, 尊重老师, 老师的谆谆教导才能发挥其 应有的作用。因此, 做好这些是处理好老师与学生之间关系的另一重要 途径。

\section{3 结束语}

处理好老师与学生之间的关系, 需要做的工作有很多。作为班主任 老师应该更加清楚地认识到学生的主体地位, 理解学生的差异, 了解学 生成长的顺序和阶段。只有充分认识到这些东西, 班主任老师才能做到 尊重学生, 才能真正地为学生着想, 从而反思自我, 找出师生交往中的 问题根源。此外, 作为教师, 也只有有专业的能力、良好的形象和个人 修养以及优良的品德, 才能真正地获得学生的信任, 在班集体中树立起 威信。做好这些, 教师才能将自身与学生的关系处理得更好, 并且通过 建立这种师生关系, 更及时地了解学生、与学生沟通, 帮助学生更快更 好地成长。

\section{[参考文献]}

[1]蔡仁学, 雷丽.浅谈如何在学生管理工作中与学生建立良好的师生 关系[J].长江丛刊,2017(11):231-231.

[2]胡小燕.高校体育教师如何与学生建立良好的师生关系[J].新校 园:阅读版,2017(5X):151.

[3]张原,王鲁娟.诌议小学班主任管理过程中与学生和谐关系的构建 [J].中华少年,2019(7):215-215. 